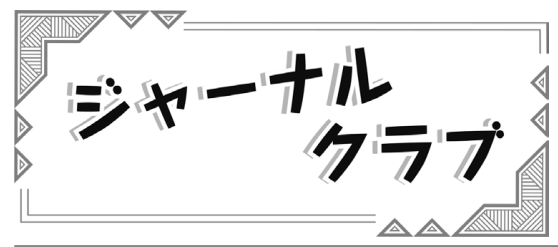

血栓止血誌 2021; 32(5): 644-646

\title{
深部静脈血栓症の除外のための臨床症状とロ ダイマーを利用した簡易な診断
}

A simplified decision rule to rule out deep vein thrombosis using clinical assessment and D-dimer.

Xu K, Wit K, Geersing GJ, Takada T, Schutgens R, Elf J, et al.

J Thomb Haemost 19: 1752-1758, 2021.

現在の深部静脈血栓症（DVT）の除外診断は，その煩雑さにより十分に使用されていない．日常診療で簡便に使用で きるものが望まれている. 本研究はDVT を疑われた患者の前向きな観察研究からの個々のデー夕から解析された. 主要 評価項目は初検または経過観察中の DVT の発症で, DVT 発症の 95\%信頼区間が 2\%未満の時に安全に除外できるとした. 4つの臨床試験（Schugents, Toll, Elf, Linkins）の3,368 人の患者が, 適格症例として解析された. 全体での DVTの発現は

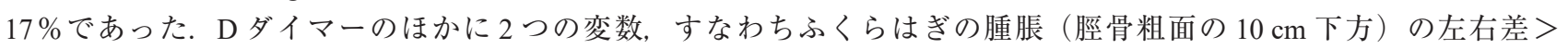

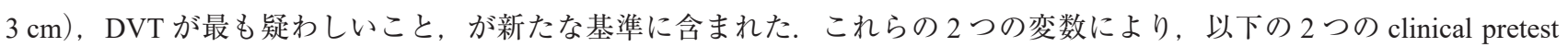
probability（CPTP）群が定義された，すなわち, 低確率（low：2つのうちいずれも該当しない）, 高確率 (high : 2つの うち少なくとも 1 つ該当)の 2 群である. D ダイマーが< $500 \mathrm{ng} / \mathrm{mL}$ の low CPTP で (発症率 $0.1 \%, 95 \%$ 信頼区間 $0.0-0.8$ ), D ダイマーが $500 \mathrm{ng} / \mathrm{mL}-1,000 \mathrm{ng} / \mathrm{mL}$ の low CPTP で (発症率 $0.3 \%, 95 \%$ 信頼区間 0.0-1.7), D ダイマーが< $500 \mathrm{ng} / \mathrm{mL}$ の high CPTP で（発症率 0.3\%, $95 \%$ 信頼区間 0.0-1.0) でDVT は間違いなく除外できた。これらの全体での感度は 98.1\%（95\%信頼区間，96.9-99.4），特異度は 49.4\%（95\%信頼区間，39.3-59.5）, negative predictive value（陰性的中率） 99.3\%（95\%信頼区間， 98.3-100）であった.

[筆者の意見 ]

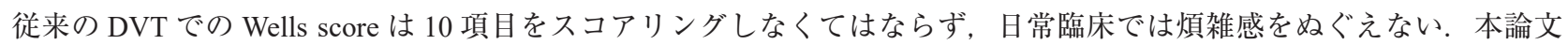
では low CPTP, high CPTCの 2 群に分類することと, low CPTP では $1,000 \mathrm{ng} / \mathrm{mL}$, high CPTC では $500 \mathrm{ng} / \mathrm{mL}$ が除外と画 像診断に進む cut off になるということである。なお D ダイマーアッセイに関しては, Tina-quant $(\mathrm{n}=814)$, VIDAS/Tinaquant $(\mathrm{n}=791)$, Auto Dimer $(\mathrm{n}=325)$, Triage（ $\mathrm{n}=1,438 ）$ と所謂高感度ではあるが, カットオフが各々異なるアッセ イ系からのデータの解析であることに注意が必要である.

（新潟大学魚沼地域医療教育センター 血液内科 関 義信）

\section{本態性血小板血症における血小板の機能と回転}

Platelet function and turnover in essential thrombocythemia: A systematic review.

Kvernberg J, Grove EL, Ommen HB, Hvas AM

Semin Thromb Hemost 47: 90-101, 2021.

本態性血小板血症は血小板数が増加する骨髄増殖性疾患である. 本態性血小板血症は欧米では 1 年間に 10 万人あたり 0.6 から 2.5 人発症するとされる. この病気は血栓塞栓症の危険率が増加すると特徵づけられており, その原因は血小板数が 増加したためであろうと考元れている。 その上, 増加した血小板の機能や回転もその原因ではないかと考えられている. 筆者らはシステマティックレビューで以下の 2 点を明らかにしょうとした. 1 つ目は, 本態性血小板血症の患者で血小板 機能や血小板回転は健常コントロールと比べて増加しているかどうか, 2つ目は, これらのパラメーターが増加した血栓 塞栓症の危険率に関連しているかどうか, さらに, このことが本態性血小板血症患者の治療決定に手助けとなっているか どうかである、筆者らは 2020 年 3 月 20 日に PRISMA（the Preferred Reporting Items for Systematic and Meta-Analysis）ガイ ドラインに従って Embase と PubMed で系統的に文献検索を行った. 合計で 1,923 の論文が確認でき, 事前に指定した選 択基準と除外基準を満たした論文は 38 件であった. 38 件のうち, 18 件で血小板の活性化が調查されており, 12 件で血 小板機能が増加していたと報告されていた。 CD36 や CD62P の血小板表面マーカーやフィブリノゲン結合が本態性血小 
板血症患者で高かったとの報告があった．CD40L や $\beta$-thromboglobulin, PF4（platelet factor 4）が高かったとの報告もあっ た. 血小板凝集能検査は 21 件で調査されており，20 件で血小板凝集能は減少していたと報告されていた．血小板の回転 （immature platelet count や mean platelet volume）は 5 件で調査されていたが，結論が出ない結果であった. 血栓塞栓症の 危険を予測するパラメーターの検討もされたが, 有効な子測因子の報告はなかった. 結論として, 本態性血小板血症患者 では, 血小板活性化は増加しているが, 血小板凝集能は減少していた. 本態性血小板血症患者での血栓塞栓症の危険の予 測因子を明らかにするような研究が今後, 望まれる.

（愛媛大学医学部附属病院 輸血・細胞治療部 山之内純）

\section{COVID-19 患者に誘発された抗 NETs 自己抗体は, NETs を安定化させる.}

Autoantibodies stabilize neutrophil extracellular traps in COVID-19.

Zuo Y, Yalavarthi S, Navaz S, Hoy C, Harbaugh A, Gockman K, et al.

JCI insight, https://insight.jci.org/articles/view/150111/pdf, 2021

新型コロナウイルス感染症（COVID-19）は, 免疫学的な血栓性炎症疾患であり, 好中球細胞外トラップ（NETs）が病 態形成に重要な役割を担っており，過剩な NETs 産生は重症化の要因となっている。また，COVID-19 患者では，抗リン 脂質抗体などの多様な自己抗体がしばしば検出され，COVID-19 の免疫学的病態形成に関与することが示唆される. 本論 文では, COVID-19 患者において, NETs を標的とした自己抗体の存在を検出し, その病態生理学的および臨床的意義を 検討している. COVID-19 の入院患者 328 人と健常対照者 48 人について，血清中 IgG 及び IgM の抗 NETs 抗体活性を ELISA により測定した，健常対照群の平均值＋2SD をカットオフ值とした場合， IgG では $27 \%$ （89人 / 328 人）， IgMで は 60\%（197人/328人）が高い抗 NETs 活性を示し, 全ての患者の IgG と IgM の抗 NETs 活性は, 相互に正相関を示した. これらの抗 NETs 活性を有する自己抗体の臨床的意義について, 他の病態生理学的マーカーとの相関を検討したところ, いずれの抗 NETs 抗体についても以下の結果が得られた. 1) 患者血清中抗リン脂質抗体（抗 cardioripinn 抗体及び抗 phosphatidylserine/prothrombin 抗体）と抗 NETs 抗体の同じサブクラス間では強い正相関を示した. 2) 血清中の NETs バ イオマーカーである calprotectin 及び MPO-DNA の濃度と有意な正相関を示した. 3）血液中の好中球数, 血小板数及び血 清中の D-dimer と有意な正相関を示した. 4) 呼吸機能について, 酸素化効率 $\left(\mathrm{SpO}_{2} / \mathrm{FiO}_{2}\right)$ と, 有意な負の相関を示した. 5）室内気吸入で酸素飽和度 $94 \%$ 以上の軽症患者（69人 $/ 328$ 人）及び人工呼吸器を要する重症患者（140人/328人）に おける抗 NETs 抗体活性の比較について, 重症患者では軽症患者に比較して有意に高值を示した，さらに，健常人血清の NETs クリアランス効果に対する患者血清中抗 NETs 抗体（IgG 及び IgM）の阻害活性を検討した. 結果として，いずれ の抗 NETs 抗体にも, NETs クリアランスの阻害活性が認められ, IgM に比較して, IgGに, より強い阻害活性が認めら れた. 結論として, 多くの COVID-19患者では, NETs クリアランスの低下を引き起こす抗 NETs 自己抗体が産生され, 血栓性炎症の増覀要因となっていると考えられる。 また, COVID-19 患者において, 遷延する抗 NETs 自己抗体の存在が, Post-COVID-19 症候群の誘因となる可能性が示唆され, 今後の検討が必要である.

(東海大学医学部基礎医学系生体構造機能学 増田治史)

コンシズマブおよび rFVIIa, APCC, rFVIII, または rFIX の存在下でのトロンビン生成能 : in vitro および ex vivo での分析

Thrombin generation potential in the presence of concizumab and rFVIIa, APCC, rFVIII, or rFIX: In vitro and ex vivo analyses. Kjalke M, Kjelgaard-Hansen M, Andersen S, Hilden I.

J Thromb Haemost 19: 1687-1696, 2021.

抗 Tissue Factor Pathway Inhibitor（TFPI）阻害モノクローナル抗体薬のコンシズマブは，インヒビターの有無に関係な く血友病 A/B（HA/HB）の出血予防のために開発された皮下注射薬で, 現在臨床研究（治験）中である.コンシズマブ投 
与中の破綻出血には，バイパス製剂（遺伝子組換え型活性化第 VIIa 因子 [rFVIIa ] 製剂抢よび活性化プロトロンビン複 合体製剤 $[\mathrm{APCC}])$ ）または第 VIII 因子（FVIII）あるいは第 IX 因子（FIX）製剤で治療を行う。その止血能は，トロン ビン生成能 (Thrombin Generation: TG) で解析されるが, 本研究の目的は, コンシズマブ投与中に rFVIIa, APCC, rFVIII，あるいはrFIX が投与された場合のトロンビン合成能を評価することである.

in vitroで, コンシズマブ単独, または rFVIIa, APCC, rFVIII と一緒にHA プール血漿に添加した. また, コンシズマ ブによる出血予防療法を受けている HA 患者の血漿にrFVIIa, APCC, およびrFVIII を ex vivoで加えた. HB プール血漿 にも in vitroで, コンシズマブ単独または rFIX と一緒に添加した，TG は組織因子で凝固反応を開始して測定された.

コンシズマブでは, 濃度依存的にトロンビンピーク值が増加した. rFVIIa, APCC, rFVIII, rFIXをそれぞれ追加すると, トロンビンピーク值はさらに増加した．コンシズマブと rFVIIa, APCC, rFVIII, rFIX 追加の効果は主に相加的であり, 薬物間相互作用によって引き起こされる余剩効果はないか, あっても最大 $25 \%$ 程度であり, 強力な相乗効果は観察され なかった.コンシズマブの存在下では, $0.5 \mathrm{IU} / \mathrm{mL}$ の $\mathrm{rVVIII}$ または rFIX で得られたトロンビンピーク值は, 非存在下に比 べてわずかに高い場合もあったが, 非存在下の $1 \mathrm{IU} / \mathrm{mL}$ の $\mathrm{rVVIII}$ または rFIX で得られたトロンビンピーク值とほぼ同等 であった。

rFVIIa，APCC，rFVIII， および rFIX は，コンシズマブの存在下で血漿トロンビン合成能を高めた。必要な止血効果を 維持しながら, 潜在的な安全上の懸念点とのバランスをとるために, 併用の場合にはそれぞれの製剤の用量レべルを適宜 調整する必要がある.

(広島大学病院輸血部・血友病診療センター 藤井輝久) 